\title{
MISCELLANEOUS COMMUNICATIONS.
}

\section{A Point in Palaeography.}

My recognition of the letter $\mathrm{H}$ /with the value $h$, instead of $\mathbf{M}, m$, on the coins of a certain ruler in Northern India (see page 1029 above), has removed the difficulty in the way of finding identically the same name on both the obverse and the reverse of the coins. The Indian legend in Kharōshthī characters on the reverse gives the name as Kharaosta; as also do the inscriptions $A$. and $E$. on the Mathura lion-capital (page 1025 f.). The Greek legend on the obverse had been taken as giving the name Kharamostis (Cunningham), Kharamosta (Bühlor and Rapson), or Charamostis (V. Smith) : and the question of identity, both of name and of person, had been argued on both sides,the chief difficulty being the supposed M. That question is now settled by my reading, XAPAHШCTEI, in the place of the previously accepted XAPAMШCTEI. This gives us, against Kharaosta as the native form of the name, ${ }^{1}$ a Greek form, Kharahōstēs, which exactly matches it except for the $h$, which was probably inserted because, otherwise, the alpha and omega, coming together, might be pronounced as $a u, a w$.

There is no room for doubt about this mattor. On the coin presented by Rapson in this Journal, 1905. 814, plate, fig. 9, the word is XAPAYWusTEl. There is no question of reading a given $\mathrm{M}$ as meaning $\mathrm{H}=h$ in order to serve a purpose: we simply take as $\mathrm{H}=h$ an undeniable $\mathrm{H}$ which

1 The third syllable seems to be distinctly o; not ho, both in the inseriptions, and on the coins. 
has hitherto been misread as $M$. And the point is made still more clear, if that is possible, by the circumstances in which the same feature occurs elsewhere (see below). The importance of it lies in the result to which it leads us.

We must first note the date of the Chhatrapa (Satrap) Kharaosta, Kharahōstēs, on whose coins we find this letter $H$ with the value $h$. He was (see page 1025 above) a grandson-daughter's son- of Rājūvula, and was consequently a nephew- sister's son- of Rājüvula's son Śodāsa. For Soḍāsa as Mahākshatrapa (Great Satrap), we have a date in A.D. 15 (page 1037). His nephew Kharaosta is therefore to be placed closely about A.D. 15 to 30 .

This use of $H$ with the value $h$ distinctly indicates a Roman influence. The characters of the legend are essentially Greek: this is shewn by the $\Pi, P, ᄃ$, and $U$. But the letter $H$ with the value $h$ disappeared from the Greek alphabets at a very early time,- according to Taylor, before B.c. 350 (The Alphabet, 2. 86); and its place there was taken by the rough breathing, which was developed from it. It was not taken back into the Greek alphabets. But it was taken into the Italic alphabets; apparently during the period B.c. 153 to 54 (see Lewis and Short's Latin Dictionary, under $\mathbf{H}$ ). It is, therefore, only under some Roman influence that the letter can have been introduced, with that value, into the otherwise Greek legends on coins of India. The letter may have been introduced into India at any. time after B.c. 21, in or about which year (see McCrindle, Ancient India, 77, 78, note 2, 212) an Indian embassy was received by Augustus: but it can hardly have been actually taken into use there until some little time after that event. The insertion of it in the name Kharahōstēs may itself be another sign of Roman influence: compare, for instance, the Latin optional form Phrahātēs alongside of the Greek Phraātēs.

We find the same Roman influence, shewn by the same letter $H$ with the value $h$, some seventy years later on the Downloaded from https://www.cambridge.org/core. University of Warwick, on 22 May 2018 at 06:41:10, subject to the Cambridge Core terms of use, available at https://www.cambridge.org/core/terms. 
coins of the "Western Kshatrapa" Nahapāna as made known to us by Mr. Scott's account, published in a recent paper in the Journal of the Bombay Branch of the Royal Asiatic Society, of the great hoard of coins of that king and of Gōtamiputa-Siri-Sātakaṇi found at Joghaltembhi in the Nāsik district.

Nahapāna's period is well established. We have (ASWI, 4. 103, No. 11) an epigraphic date for him as king in the year 46 (of the so-called Śaka era of A.D. 78), = A.D. 124-25. An earlier epigraphic date is furnished for him by a record of his son-in-law Ushavadāta (ibid., 102, No. 9 ; EI, 8. 82), which is dated in the month Vaisākha, the year 42, falling in A.D. 120. And an earlier date still, between A.D. 80 and 89 , is furnished by the author of the Periplus of the Erythraean Sea, who, writing in that period, tells us (see, e.g., McCrindle's translation, IA, 8. 140) that the then king of a certain territory, which we can identify as including Kāthiāwăd which was part of the territory of Nahapāna, was Mambanos, - (or may we say Mambanes? ${ }^{1}{ }^{1}$ - whose identity with Nahapāna has already been established by M. Boyer (JA, 1897, 2. 134-8). ${ }^{2}$

1 It must have been by some slip of the pen that McCrindle presented this name as Mombaros, with o (instead of $a$ ) in the first syllable. $\mathrm{He}$ was using the text published by Didot in Geographi Graeci Minores, vol. 1, which (p. 289)

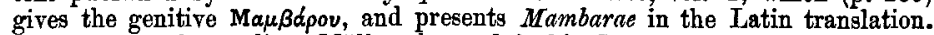
In respect of the reading, Müller observed in his Prolegomena, p. 144, that we should read Ma $\mu \beta$ divov with the codex.

2 We can now see more clearly how the name Nahapana became transformed into Mambanos or Mambanēs. The ease with which the $\mathrm{H}$ as eta (and necessarily also as $h$ ), the $\mathbf{M}$, and the $\mathbf{N}$ might, at any rate in their cursive forms, all be confused with each other, is well illustrated by the coins of Kanishka and Huvishka. It may also be well recognized in the table of cursive Greek characters given by Sir Edward Maunde Thompson in his Greek and Latin Palcography, at page 148 .

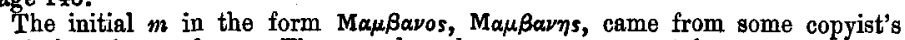
confusion of $m i$ and $m u$. The second $m$, however, came, not from any insertion of an $m$, under phonetic influence or otherwise, as in the case of Palibothra, Palimbothra, but from a similar confusion of $h$ and $m u$ : just as modern numismatists have been mistaking $H$ for $M$ on the coins of Kharaosta, Kharahōstēs, so some ancient copyist- (or possibly the author of the Periplus himself, in citing the name from a coin) - made the same mistake with the name of Nahapāna, written, not exactly in its full form NAHA MANA, but, with the omission of an alpha, as NAHПANA, in which form it actually occurs on

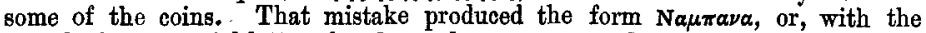

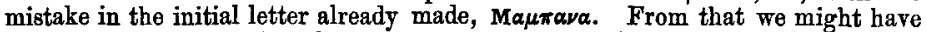
Ma $\mu \beta \alpha \nu \alpha$ under phonetic influence : or a cursive pi might easily be mistaken by a eopyist for a cursire beta (see Thompson's table of the Greek oursives). 
These coins of Nahapāna bear legends in Brāhmin, Kharōshțhi, and Greek characters, which I transcribe from some specimens kindly shewn to me by Mr. J. S. Cotton. The Greek legend is on the obverse: the Brâhmi and Kharōshțī legends stand together on the reverse. ${ }^{1}$

The Brāhmī legend runs-

Rãjñō kshaharätasa Nahapānasa; "of the king, the Kshaharäta, Nahapāna."

The Kharōshṭ̂i legend runs-

Raña ${ }^{2}$ chhaharatasa Nahapanasa; and has the same meaning.

The Greek legend is a transliteration of the Indian legend, with an omission of the final $a$ of the two genitives ending in $s a$ : in its fullest form, it runs (with sometimes $Z$ instead of $I$ as zeta) -

\section{PANNIW IAHAPATAC NAHAMANAC.}

Here, in a legend which again is essentially Greek, as is shewn by the $I, \Pi, P$, and $\omega$, we have again, under Roman influence, the $\mathrm{H}$ with the value $h$ in two words; the proper name nahapãna, and the tribal or family name zaharäta $=$ chhaharäata, kshaharäta, - the kshaharäta and khakharäta of inscriptions : (e.g., ASWI, 4. 99, No. 5, line 1 ; 108, No. 18, line 6 : EI, 8. 78, line $1 ; 60$, line 6).

In connexion with certain views which would place Kanishka more or less after Nahapāna, we naturally look for the same Roman influence in the coins of the Kanishka group. But we look in vain. The $H$ with the value $h$ is not found there. And, not only is it absent, but in two cases at least it is conspicuously absent.

1 There are twenty-four characters - (should have been twenty-six) - in the Greek legend, but only twelve in each of the others.

2 No doubt some of the coins present raño, as read by Mr. Scott. But there is no clear instance of the $\bar{o}$ in the specimens seen by me. The Greek transliteration rannio is interesting, as illustrating the pronunciation of $j \tilde{n}$ and $\tilde{n}$, $\tilde{n} \tilde{n}$, with the $y$-sound. 
The first case is in the treatment of the name Hurishka: This is usually represented by oohPKE, oohPKI, and oohpKo. There are also two exceptional forms on a. few coins attributed to Huvishka : Gardner has read oYohPKI from three coins, not: figured (Catalogue of the Coins of the Greek and Scythic Kings of Bactria and India, 137 , No. 15 ; 142 , No. 52 ; 149, No. 110$)$; and a coin given by Cunningham in his Coins of the Kushans, plate 23, fig. 8, presents o rohpK[€, l, or o]. There is certainly no $\mathrm{H}, h$, in any of these forms. But is there any $h$ at all in the treatment of this name?: the point is worth considering, though it is only a side,issue.

On the hypothesis that 0 means sometimes $h$, as. well as $v(w)$ and $u$, on the coins of the Kanishka group, we might: transliterate the last two forms, given above, into Huvesshki. ${ }^{1}$ But we cannot treat the other three forms in that way : in oompKE; ${ }^{\circ} \mathrm{Kl}$, ${ }^{\circ} \mathrm{Ko}$, there are not letters enough for us to find Huvēshke, 'ki, "ko; while Hvēshke, etc., which on the said bypothesis we might find, would represent the original name imperfectly : and it may be added that Wesske, etc.,

1 Dr. Stein's case for an $h$-value of 0 rests chiefly (IA, 17.91, 95) upon the name MAO as = the Pahlavi and modern Persian Màh, the Moon-god, and upon the regal title PAONANOPAO as = shähanano shäh as a form of the. Iranian shăhan-shäh. I have no special object in denying the possibility. But Dr. Stein himself has indicated Mân as the Avesticname of the Moon-god; and we have $O=$ clearly $u, w_{\text {i }}$ at least in $\mathrm{O} \triangle \triangle \mathrm{O}$, the Wind god, the Vedic Vata, Wäta, and probably in $O A N I N \triangle O,=$ Vanaiñti-(uparatàt); and it seems to me that the cases, specially relied upon by him are fully met by treating the $O$ as o itself, with the value $u, w,-$ especially since, in another of his cases, against the usual P A OP hoPo we have an instance of D AYPhOPO (Cunningham, Coins of the Kushāns, plate 22, fig. 9). We may also ask:- If o had sometimes the value $h$, why was not the first component of the Indian name Mahāsēna (see page 1047 below) transliterated by MAOA?

This question about the $h$-value of $O$ may be considered fully when we come to deal with the name ofPo, ohPA; Oésho, Oësha (in one exceptional case oh २०, 0ẽzo), applied to a god who is unmistakably siva. I regard this word as a very good attempt to represent in Greek the Sanskrit Vrisha, as pronounced Wrisha or Wisha, which, in addition to denoting Siva's bull, was an appellation of Siva himself as 'the rain-maker.'

The words quoted in this note, and some of those quoted in my text, ought to be shewn in cursive characters. But it has not been found convenient to do so on this occasion. 
which we might find on the analogy of another name mentioned below, would fail to represent the original name properly at all.

I can only treat the forms oOHPKE, 'KI, ${ }^{\circ} \mathrm{Ko}$, as follows. The first o represents $u$ : as also, on coins, in BA २० $\triangle$ ho $=$ Vāsudēva, Vāsudēw ; Bo $\Delta \Delta \mathrm{o}=$ Buddha ; KoMAPo $=$

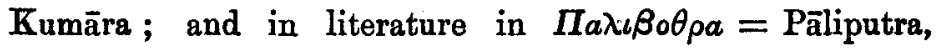
Pātaliputra. The second o has again the value of $u$, but, standing between two vowels, it takes the almost inevitable sound of $w$, and answers to a $w$-sound of the $v$ in the original name. The $h$, eta, here and in KANHPKOY and $\mathrm{KANhPKI},=$ Kanishka, Kanishka, represents $i:^{1}$ as also in oOHMO and oohMO = Vima, pronounced Wima (in this legend the $w$ is oo, literally "double- $u$," instead of simply o)..$^{2}$ The $h$ of the original name is not represented, but is to be found in the rough breathing understood: as in the case of $\mathrm{H} \wedge \mathrm{OOC}=(") \bar{E}$ lios on coins of Kanishka (Gardner, plate 26, fig. 2; Cunningham, Coins of the Kushäns, plate 16, figs. 1,3$), H Ф A \mid C T O C=(") \bar{E}$ phaistos on coins of the same

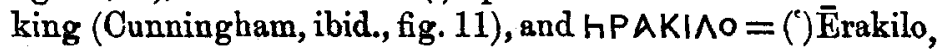
Hēraklēs, on coins of Huvishka (Gardner, plate 27, fig. 15; Cunningham, op. cit., plate 23 , fig. 13). ${ }^{3}$

Thus, the Greek forms of the name of this king, which transliterate literally into Ooēshke, ${ }^{\circ} \mathrm{ki}$, ${ }^{\circ} \mathrm{ko}$, denote respectively (") Uwishke, ${ }^{\circ} \mathrm{ki}$, ${ }^{\circ} \mathrm{ko},=$ Huvishka pronounced as Huwishka. Anyhow, the point remains that the Latin H, $h$, is not found in the transliteration of the name Huvishka : and yet it is at least difficult to believe that it would not have been used in that case, if it had been known in India in his time.

\footnotetext{
I We have something very similar, namely an eta representing a long $\bar{i}$, in

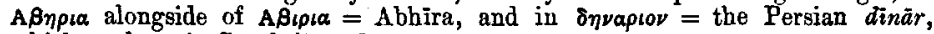
which we have in Sanskrit as dinära.

2 Professor Rapson has shewn us that the first component of the native name of this nember of the Kadphisẽs group is Vima, not Hima or Hema as had previously been supposed: see the Transactions of the Fourteenth Oriental Congress, Algiers, 1905, Indian Section, p. 219.

3 It appears probable that the first step was the same in the production of the literary form 'Epavvoßoas = Hiraññabäha, Hiraṇyavāha: first, the rough breathing was understood, and then it seems to have been lost under the influence of epavpos, 'lovely,' applied particularly to places.
} 
Curiously enough, against the omission of the rough breathing as illustrated above, we have on another coin of Huvishka a distinct instance of the use of it, in a cursive form and prefixed to an eta. That instance, however, does not enter into our present argument, which is the absence of the Latin $\mathrm{H}, h$, from all the coins of the Kanishka group : it is treated elsewhere. ${ }^{1}$ We confine ourselves here to exactly what we have in hand.

A still more pointed instance of the absence of the Latin $\mathrm{H}, h$, from the coins of Huvishka is found in the treatment of the name of the Indian god Mahāsena: for being able to exbibit it here, I am indebted to Mr. Allan, of the British Museum, who kindly made the drawings from which the legends are reproduced. We have one case in the coin figured by Gardner in his plate 27, fig. 16, and by Cunningham in Coins of the Kushâns, plate 20, fig. 15: here the name is presented as HaDr-kro, Maasēno, with (as we may like to take it) either an imperfect alpha, or a mistake of delta for alpha, in the third letter. And we have it again, on another coin of the same class, as MALF ho (Gardner, 138, No. 24; not figured). ${ }^{2}$ We might perhaps discount the absence of the $\mathrm{H}=h$ from the Greek transliteration of the name Huvishka. But it is out of the question to believe that, if the letter had been known in India in his time, it would not have been duly used in a case in which it is so essential as in the transliteration of the name Mahāsēna. ${ }^{3}$

1 See my note "A Coin of Hurishka," in the next number of this Journal.

2 This is, perhaps, Mr. Thomas' fig. 10 in his plate in this Journal, 1877, 212 ; or it may be from the same die with Mr. V. Smith's plate 12, fig. 8. The name occurs again as Masēno in Gardner's plate 28, fig. 24 ; Cunningham's plate 20, fig. 17 : where, however, the legend is too small to be drawn. It also occurs in the same way (Mr. Allan tells me) on a fourth coin, originally belonging to Sir A. Cunningham, now in the British Musseum: I have not reproduced this legend, because it is practically identical with the second one given above.

${ }^{3}$ It is the case that there are instances amongst the coins of Nahapana in which, instead of the second alpha being omitted as in the form NAHMANA (see note 2 on page 1043 above), the $h$ was omitted and the alpha was preserved. But the legend had then become corrupted in various ways: the initial nu was reversed; the Latin $P$ was substituted for the Greek $\Pi$; the third alpha also 
As regards the origin of the era of - B.c. 58 , the position now stands as follows.

I have shewn (this Journal, 1906. 979 ff.) that the Buddhist tradition, putting Kanishka, king of Gandhāra, Kashmir, and (Northern) India, 400 years after the death of Buddha, places his initial date practically in в.с. 58 .

I have also shewn (page $169 \mathrm{ff}$. above) that we have from Northern India a regular series of dates in an unnamed era, from the year 3 coupled with the name of Kanishka to the year 399 , which, if they are referred to the era of B.C. 58 so that they range from B.c. $55-54$ to A.D. $342-43$, practically fill the period antecedent to the point of time, in A.D. 372, from which Professor Kielhorn took up the history of the era under the names first of the Malava era and then of the Vikrama era.

Dr. Franke, working in quite another line of research, has shewn, from the Chinese sources, that the initial date of Kanishka must be placed appreciably before B.c. 2, and máy, in fact, be most appropriately placed in B.c. 58: see his article “Beiträge aus Chinesischen Quellen zur Kenntnis der Türkvölker und Skythen Zentralasiens" in the Proceedings of the Royal Academy of Sciences of Prussia, 1904, and the abstract translation of passages from it, relating in particular to the Sök and Kanishka, given in the Indian Antiquary, 1906. $33 \mathrm{ff}$.

We have now added the following two points. The Latin letter $\mathrm{H}, h$, is found in Northern India, in the legend which is otherwise Greek, on coins of the Satrap Kharaosta, Kharahōstēs, who is to be placed closely about A.D. 15 to 30 . And that letter is absent, and conspicuously so, from the legends on the coins of Huvishka, a successor of Kanishka, which come from the same part of India.

was omitted; and so (see the illustrations given with Mr. Scott's article) we have such forms as UAAPNAA ... and UAAPNAACCE.

Even in the best specimens of their work, Nahapana's die-sinkers were unable to bring the whole of the Greek legend onto their dies. But they were careful to omit from those specimens only the comparatively unimportant final $a$ of the genitives zaharatasa and nahapanasa. Huvishka's die-sinkers, however, were not hampered in that manner at all: there was ample robm to insert the $h$ on the Mahäsena coins, if it had then been known. 
From the last two points, we arrive at the result that Huvishka must be placed before A.D. 15 to 30 . For Huvishka we have dates, ranging from the year 33 (IA, 6. 217 , No. 2 ; EI, 8. 182) to certainly the year 51 (the wellknown Wardak vase) and perhaps to the year 60 (EI, 1 . $386)$, from the same series of records: with the dates that range back to the year 3 for Kanishka. And the era of B.c. 58- the historical era of Northern India, and the only Indian era dating from, or even existing in, the first century B.c. - meets here, again, the requirements of the case, by placing before A.D. 15 , but not too long before that year, the equivalent of the latest known date for Huvishka, whichever that may be:

With all these results before us, we may now take as established my case that the dates for Kanishka and Huvishka are dates in the era of B.c. 58 , with the result that the era was founded by Kanishka; subject, of course, to the possibility (which, however, is not a strong one) that a predecessor of Kanishka may have reigned in the first two years of the reckoning, in which case such predecessor would be the founder of the era, and Kanishka would be the establisher of it. For the present, at any rate, we need go no farther: the rest is simply a matter of detail,a question, as I have intimated before now, of framing: views about coins, art, and palaeography in accordance with facts, instead of ignoring facts in favour of illusory theories.

$$
\text { J. F. FLEET. }
$$

\section{Vethadipa; Visnudvipa.}

In a previous number of this Journal a conjecture was made by Dr. Fleet regarding the Sanskrit form of Pāli Vethadipa. Subsequently the identity of this place with Betiyā in Campāran district, suggested by Dr. Hoey, was proved by Dr. Grierson on linguistic considerations to be untenable. ${ }^{1}$ Vethadipa is twice mentioned in the Maha- 